\title{
The role of advertising through social networks to promote brand equity
}

\author{
Fereshteh Mansouri Moayyed $^{\mathrm{a}}$, Saeed Dehyadegari ${ }^{\mathrm{b}}$ and Alireza Bakhshizadeh ${ }^{\mathrm{a}^{*}}$
}

${ }^{a}$ Department of Management and Economics, Tabriat Modarres University, Tehran, Iran ${ }^{b}$ Shahid Bahoner University of Kerman, Kerman, Iran

\begin{tabular}{|c|c|}
\hline ART I C L E I N F O & A B S T R A C T \\
\hline $\begin{array}{l}\text { Article history: } \\
\text { Received April 17, } 2012 \\
\text { Accepted 11 June } 2012 \\
\text { Available online } \\
\text { June } 12 \text { 2012 } \\
\text { Keywords: } \\
\text { Social networks } \\
\text { PepsiCo } \\
\text { Advertisement } \\
\text { Brand equity } \\
\text { Brand loyalty } \\
\text { Perception quality }\end{array}$ & $\begin{array}{l}\text { Social networks are online gathering places for people who would like to share their interests } \\
\text { and activities. In this context, advertising through social networks is one of the most important } \\
\text { topics in the field of marketing and brand that has been considered only in few studies. This } \\
\text { study examines the impact of advertising on brand equity through social networks in the } \\
\text { beverage industry (PepsiCo). This research study was to survey and collect data from the a } \\
\text { standard questionnaire. PepsiCo brand, which is a well known beverage industry worldwide is } \\
\text { selected for the proposed study of this paper. Thus, all customers of Pepsi products in city of } \\
\text { Tehran are considered as statistical research community and a sample size of } 385 \text { people is } \\
\text { selected for the proposed study. In order to analyze the data, we use structural equations method } \\
\text { and certified factor analysis. The results of our survey indicate that advertisement on social } \\
\text { networks has a positive impact in this industry. Based on the results of our survey, we realize } \\
\text { that there are some positive relationship between social network advertisement and quality } \\
\text { perception, brand loyalty, brand awareness and brand association when the level of significance } \\
\text { is one percent. }\end{array}$ \\
\hline
\end{tabular}

\section{Introduction}

Social network is a structure of nodes, which consists of individuals or organizations and they are connected through one or different kinds of relationships such as social or family relationship, financial affairs, etc. (Swamynathan et al., 2008). In general, when people join to social networking sites and become a member, they share a profile of their data with them. When there are some online profiles, the other people may look for people with the same interests and profiles and they share their information. Anyone who wants to become a member of social networks must find a relationship with another person who is already a member of social network. This is a simple procedure that people can contact with each other and inform the other people about their interests. Since social network users have the desire to communicate to each other, it creates good motivation among them to advertise different goods and services (Lorence, 2007).

* Corresponding author. Tel: 989132219199

E-mail addresses: abakhshizadeh@ymail.com (A. Bakhshizadeh) 
In social networks, users share their thoughts and recommend different products and services, which is a good way to buy a particular product. One survey indicates that approximately, 78 percents of worlds' consumers believe they prefer that word of mouth for buying a product is better than any other method. There are also many evidences to believe that any advertisement coming from friends are more likely to be honest and unbiased compared with what they hear from different mass media. According to Wasserman and Katherine (1994), social networks could even provide different necessary information for big corporations to exposure their businesses, to adjust their prices and to do some coalition with other business units. Social networks can cover large audiences and it is one of the most important advertising medium for companies. A large soft drink companies like Pepsi and Mercedes-Benz automobile spend significant amount of money per year for advertising on social networks such as Facebook and Twitter, which means this is an effective way for advertisement.

The primary objective of this paper is to consider the effect of advertisement through social network on shaping and developing brand value. We first present brand value and its perspectives and explain details of our findings on the impact of advertisement through social network.

\section{Problem statement}

\subsection{Brand equity}

There are literally different definitions for brand equity such as a set of assets and liabilities associated with the brand name and symbol of the value provided by a product or service for customers. It can be also defined as distinguish effects of brand knowledge on consumer response to brand marketing. A power built by a symbol, name or brand and finally value added or given prizes from products to a customer are among some definitions for brand (Yoo et al., 2000; Anand et al., 1988; Keller, 1993).

If a particular customer concludes that there is a significant difference between various brands and this becomes an important purchasing information, then we could expect that customer can increase purchasing decisions as brand equity increases. Brand equities play valuable assets in many organizations (Anand et al., 1988). Brand equity is normally discussed in both financial and marketing literatures (Parker, 2005). The focus of this paper is more on customer-based brand equity, which is commonly used within the marketing literature.

In terms of customer-based brand equity perspective, we need to look at the sources of brand value creation (Keller, 2008). In other words, brand power depends on what customers feel during the time or what they have heard (Keller, 2003). Brand creates value for customers and also provides value for the organization and it is the main source of value, which lies in customer' mind (Keller, 2001). According to Konecnik and Gartner (2007), brand equity consists of four perspectives of awareness, image, quality and loyalty.

Awareness refers to people's capabilities on detecting a particular brand. Image presents on customers' perception from a particular brand. Quality determines the quality characteristics of a particular brand and customer loyalty is associated with customers' positive perception towards a particular brand and increases purchasing frequencies (Martinez et al., 2009). Next, we explain details of these items according to Aaker $(1996,1996)$.

\subsubsection{Quality perception of a brand}

This item judges on relative advantages of a particular product compared with other similar products. These days, many firms have decided to choose customer based strategy and do their business based on what their customers are looking for. 


\subsubsection{Customer awareness}

The other important issue in product selection is to know more about product's characteristics and have a good perception. Awareness means how many people know a particular brand and what percentage of the people have small amount of information on brand. Awareness of brand maintains three advantages as follows,

1. Top of mind awareness: When people start talking about a product people could easily remember the image of the brand.

2. Awareness with no help: This measures how famous a particular brand is.

3. Guided awareness: This asks audiences whether they have heard about the name of a particular product and its brand or not.

\subsubsection{Brand association}

Anything such as place, store, symbol, plan, life style, etc. that could help customer build an image from a particular brand could contribute to brand. According to Aker and Joachimsthaler (200), brand associate is a set of assets, which are responsible to build a relationship with customers.

\subsubsection{Brand loyalty}

Brand loyalty is relatively biased behavioral response in an individual purchases over time and this causes positive impact on people's decision on purchasing products (Chaudhuri \& Holbrook, 2001). Brand loyalty is a function of different psychological and perceptional aspects of people's behavior. Brand loyalty could increase word of mouth's advertisement and it can create a serious obstacle for competitors to enter the market. A significant number of loyal customers is considered as an asset for a firm. Loyal customers normally are not sensitive to price fluctuations. According to Sahin et al. (2011) any word such as repeat purchase, preference, commitment and allegiance are associated with customer loyalty. The customer-brand relationship plays an important role in building customer loyalty (Fournier \& Mick, 1999; Chiou \& Chung, 2006). A good brand experience could increase brand loyalty and it could increase profitability (Morrison \& Crane, 2007).

\subsection{Advertisement}

Advertisement is the magic of $20^{\text {th }}$ century and marketing without advertisement has no meaning. Products could be profitable when it can influence different people in the world and this happens only by using an appropriate method of advertisement. There are literally many different methods for advertisement such as TV advertisement, Magazines, etc. (Arens, 2005).

\subsection{Advertising through social networks}

Social networks are strong power to shape business structures since they improve world of mouth advertisement and facilitates customers' decision making process. In order to succeed in such a market, marketing strategies must be familiar with different roles of advertisement on social network. Although social networks are considered as precious resource of advertisement but they could be more important than advertisement itself since a huge numbers of messages are exchanged among people and it is not possible to handle or make a necessary responses to all these messages. There are many discussions on social networks such as Facebook or Twitter and their impacts on marketing. Many companies have created their own pages on these social networks in an attempt to have more exposure into market. While there are many discussions on word of mouth advertisement on the 
internet but the effects of these web pages are still unknown (Chapman, 2008). Based on what we have explained, the following conceptual model is considered for the proposed study of this paper.

The proposed study of this paper is performed in capital city of Iran, Tehran and by performing a simple sampling technique as follows,

$n=\frac{z_{\alpha / 2}^{2} p . q}{d^{2}}=\frac{1.96^{2} \times 0.5 \times 0.5}{0.05^{2}}=395$.

Therefore, we have chosen 385 people who lived in this city and they were familiar with Pepsi-co product, which is an international beverage producer. All questions were designed in Likert scale in five different ranges from completely disagree to completely agree.

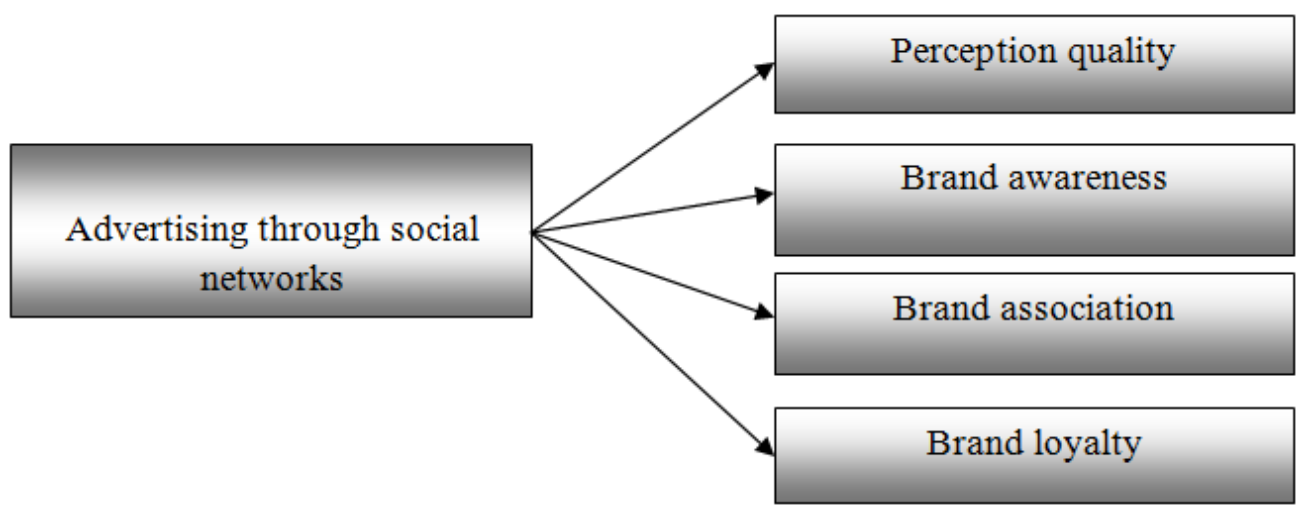

Fig. 1. The proposed framework

\section{The results}

In this section, we have used structural equation method (SEM) to analyze the results of our survey and Fig. 2 shows details of our survey.

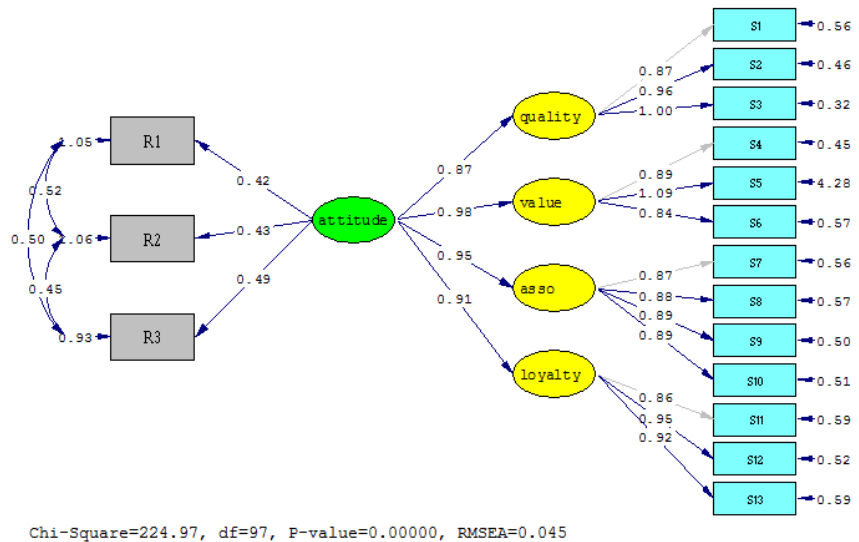

Fig. 2. The results of the implementation of SEM

In order to determine the goodness of the fit for the proposed study of this paper we have used factor analysis and the results are summarized in Table 1, where the actual values along with desirable values are given. As we can observe from the results, the proposed model of this paper represents reliable results. 
Table 1

The results of Factor analysis

\begin{tabular}{lll}
\hline Attribute & Value & Desired value \\
\hline$\chi^{2}$ & 224.97 & \\
Df & 97 & Less than 3 \\
$\chi^{2} /$ df & 1.98 & Less than 0.1 \\
RMSEA & 0.045 & Greater than 0.9 \\
NFI & 0.99 & Greater than 0.9 \\
NNFI & 0.99 & Greater than 0.9 \\
CFI & 0.99 & Greater than 0.9 \\
IFI & 0.99 & Greater than 0.9 \\
GFI & 0.96 & Greater than 0.8 \\
AGFI & 0.94 & Less than 0.05 \\
RMR & 0.040 & \\
\hline
\end{tabular}

Table 2 shows details of questions of the survey and associated Cronbach alpha for validity and reliability of the questionnaire.

\section{Table 2}

Questions, Cronbach alphas, validity and reliability of the questionnaire

\begin{tabular}{lll}
\hline Question description & Standard factor & Cronbach alpha \\
\hline Perception quality & 0.87 & 0.841 \\
Pepsi offers good quality services and products. & 0.96 \\
\hline Pepsi continuously improves service quality and its products. & 1.00 \\
\hline Pepsi offers reliable services and products. & 0.89 & 0.790 \\
\hline Brand awareness & 1.09 \\
When I think about beverages, Pepsi is one of brands, which comes to my mind. & 0.84 & 0.868 \\
I am very much familiar with Pepsi. & 0.87 & \\
I can easily make a distinction between Pepsi and other products. & 0.88 \\
\hline Brand associate & 0.89 \\
The reason I choose Pepsi is because of its diversity in its products. & 0.89 \\
\hline I have always had good experience on Pepsi products. & \\
I remember attractive advertisement of this brand. & 0.85 \\
As soon as I hear the name of Pepsi, I remember its logo. & 0.95 \\
\hline Brand Loyalty & 0.92 \\
\hline I think I am loyal to this brand. & & 0.835 \\
In beverage industry, Pepsi is my first choice. & 0.42 \\
As long as I have the access to Pepsi, I do not buy other products. & 0.43 \\
\hline Advertising through social networks. & 0.49 \\
Pepsi has creative advertisements. & 0.795 \\
\hline Pepsi has innovative advertisements. & \\
\hline Pepsi has distinctive advertisements from others. & \\
\hline
\end{tabular}

Table 3 shows details of our survey on correlations among five major components of the survey.

Table 3

Correlation ratios among five components of the proposed study

\begin{tabular}{llllll}
\hline & Quality & Value & Association & Loyalty & Attitude \\
\hline Quality & 1.00 & & & & \\
Value & 0.86 & 1.00 & & & \\
Association & 0.83 & 0.92 & 1.00 & 1.00 & 1.00 \\
Loyalty & 0.79 & 0.88 & 0.85 & 0.91 & \\
Attitude & 0.88 & 0.98 & 0.94 & & \\
\hline
\end{tabular}

Finally, Table 4 shows details of our finding about four hypotheses.

\section{Table 4}

The summary of the results of four hypotheses $\left({ }^{*} \mathrm{p}<0.05{ }^{* *} \mathrm{p}<0.01\right)$

\begin{tabular}{lllll}
\hline Hypothesis & t-student & $\beta$ & $r^{2}$ & Result \\
\hline The effects of attitude on quality perception & $19.14^{* *}$ & 0.87 & 0.44 & $\mathrm{H}_{1}$ is accepted \\
The effects of attitude on brand perception & $23.15^{* *}$ & 0.98 & 0.56 & $\mathrm{H}_{1}$ is accepted \\
The effects of attitude on brand associate & $21.05^{* *}$ & 0.95 & 0.69 & $\mathrm{H}_{1}$ is accepted \\
The effects of attitude on brand loyalty & $19.35^{* *}$ & 0.91 & 0.66 & $\mathrm{H}_{1}$ is accepted \\
\hline
\end{tabular}


Based on the results of Table 4, we realize that there are some positive relationship between social network advertisement and quality perception when the level of significance is one percent. The tstudent represents meaningful value, which means there is a meaningful relationship between quality and perception. Similarly, we can understand that there are some positive and meaningful relationship between the effects of attitude and brand perception, associate and loyalty.

\section{Conclusion}

In this paper, we have investigated the impact of advertising on brand equity through social networks in the beverage industry (PepsiCo). Based on the results of our survey, we realized that there were some positive relationship between social network advertisement and quality perception, brand loyalty, brand awareness and brand association when the level of significance is one percent.

\section{References}

Aaker, D. A. (1991). Managing Brand Equity. New York: Macmillan, Free Press.

Aaker, D.A. (1996). Building Strong Brands. The Free Press, New York, NY, 35-71.

Aker, D.A. \& Joachimsthaler, E. (2000). Brand Leadership. The Free Press, New York, NY.

Anand, P., Holbrook, M.B. \& Stephens, D. (1988). The formation of affective judgments: The cognitive affective model versus the independence hypothesis. Journal of Consumer Research, 15, 386-391.

Buil, I., Chernatony, L.D., \& Martinez, E. (2008). A cross-national validation of the consumer-based brand equity scale. Journal of Product \& Brand Management, 17(6), 384-392.

Chaudhuri, A. \& Holbrook, B. M. (2001). The chain of effects from brand trust and brand affects to brand performance: The role of brand loyalty. Journal of Marketing, 65, 81-93.

Chapman, T. (2008). Social Network Marketing, Engagement Marketing and Brands, London Press, 1314.

Fournier, S., \& Mick Glen, D. (1999). Rediscounting satisfaction. Journal of Marketing, 63, 5-23.

Keller, K. L. (1993). Conceptualizing, measuring, and managing customer-based brand equity. Journal of Marketing, 57(1), 1-22.

Keller, K. L. (2008). Strategic Brand Management-Building, Measurig, and Managing Brand Equity, $3^{\text {rd }}$ ed., United States: PEARSON - Prentice Hall.

Keller, K. L. (2001). Building Customer-Based Brand Equity. Marketing Management, 10(2), 14-19.

Keller, K. L. (2003). Understanding brands, branding and brand equity. Interactive Marketing, 5(1), 7-20.

Keller, K. L. (2003). Strategic Brand Management: Building, Measuring and Managing Brand Equity, $2^{\text {nd }}$ ed., Prentice-Hall, Englewood Cliffs, NJ.

Konecnik , M., \& Gartner , W.C. (2007). Customer - based brand equity for a destination. Annals of Tourism Research, 34(2), 400-421 .

Morrison, S., \& Crane, G. F. (2007). Building the service brand by creating and managing an emotional brand experience. Journal of Brand Management, 14, 410-421.

Parker, T. B. (2005). This brand's for me: Brand personality and user imagery based self-Congruity. Published Doctoral Dissertation, University of Florida.

Sahin, A., Zehir, C., \& Kitapaci, H. (2011). The effects of brand experiences, trust and satisfaction on building brand loyalty: An empirical research on global brands. Procedia Social and Behavioral Sciences, 24, 1288-1301.

Swamynathan, G., Wilson, C., Boe, B., Almeroth, K., \& Zhao, B.Y. (2008). Do Social Networks Improve E-Commerce? A Study on Social Marketplaces, Department of Computer Science, UC Santa Barbara, CA 93106.

Yoo, B., Donthu, N. \& Lee, S. (2000). An examination of selected marketing mix elements and brand equity. Journal of the Academy of Marketing Science, 28(2), 195-211.

Wasserman, S., \& Katherine, F. (1994). Social Network Analysis: Methods and Applications. Cambridge University Press.

William F. A. (2005). Contemporary Advertising and Promotion. McGraw-Hill Publication, USA. 